\title{
Immunotherapeutic strategies for glioma treatment
}

\author{
George A. Alexiou ${ }^{1}$, Athanassios P. Kyritsis ${ }^{1,2}$ \\ ${ }^{1}$ Neurosurgical Research Institute, University of Ioannina, 45110 Ioannina, Greece. \\ ${ }^{2}$ Department of Neurology, University Hospital of Ioannina, 45110 Ioannina, Greece.
}

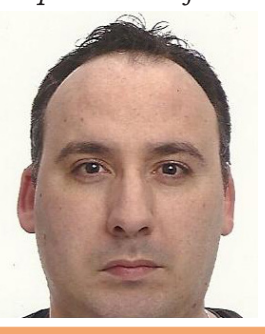

Dr. George A. Alexiou is a Neurosurgeon working at the Neurosurgical Research Institute of the University of Ioannina in Greece. His main research interests are in Neuro-oncolgy, new treatments for brain tumours and Pediatric Neurosurgery.

Glioblastoma is the most common and malignant primary brain tumor. Despite intensive clinical investigation and several novel therapeutic approaches, the median survival continues to remain poor and it is usually in the range of fifteen months. Immunotherapy is a beacon of hope for cancer treatment and offers a different approach against glioma. Various approaches have been used, such as dendritic cell based vaccines, peptide vaccines, T-cell-based therapies and immune checkpoint blockade with promising results. This paper provided an overview of the results of the most exciting immune therapeutic strategies for the treatment of gliomas.

Key words: Glioma; immunotherapy; vaccines

\section{INTRODUCTION}

Glioblastoma (GBM) is by far the most common type of primary brain tumor in adults. This devastating disease is usually incurable and virtually all GBM patients succumb despite treatments that consist of surgery, radiotherapy and chemotherapy. The median survival time remains in the range of 15 months. ${ }^{[1,2]} \mathrm{GBM}$ is an heterogenous tumor and there is great variability regarding response to treatment and outcome. Verhaak et al. ${ }^{[3]}$ developed a molecular classification of GBM into Classical, Mesenchymal, Proneural and Neural subtypes based on gene expression. Epidermal Growth Factor Receptor amplification and the absence of p53 mutations characterize the Classical subtype, whereas the Mesenchymal subtype is characterized by deletions or mutation of the gene and the Proneural subtype

Corresponding Author: Dr. George A. Alexiou, Neurosurgical Research Institute, University of loannina, 45110 loannina,

Greece. E-mail: alexiougrg@yahoo.gr

\begin{tabular}{|l|l|}
\hline \multicolumn{2}{|c|}{ Access this article online } \\
\hline Quick Response Code: & Website: \\
\hline & Www.nnjournal.net \\
\cline { 1 - 2 } & \\
\hline
\end{tabular}

is characterized by alterations of Platelet Derived Growth Factor A and point mutations in cytosolic isocitrate dehydrogenase. A clinical significance was also reported, concluding that therapeutic approaches need to be GBM subtype-specific. ${ }^{[3]}$

Immunotherapy is an attractive treatment option that involves the stimulation of patient's immune system against cancer cells with high specificity and minimal toxicity. ${ }^{[4]}$ In the late 1800s, William B. Coley, a pioneer in immunotherapy, was the first who injected a mixture of live streptococcus bacilli and subsequently heat-killed streptococcus into sarcomas and induced regression of these tumors. ${ }^{[5]}$ GBM cases of increased survival after bacterial infection have been documented, whereas patients with neutrophil to lymphocyte ratio in the blood that exceeded 4.7 differ significantly from those with neutrophil to lymphocyte ratio lower than 4.7 and were associated with worse survival. ${ }^{[6,7]}$ Nevertheless, GBM can evade by several mechanisms immune surveillance, such

This is an open access article distributed under the terms of the Creative Commons Attribution-NonCommercial-ShareAlike 3.0 License, which allows others to remix, tweak, and build upon the work non-commercially, as long as the author is credited and the new creations are licensed under the identical terms.

For reprints contact: service@oaepublish.com

Cite this article as: Alexiou GA, Kyritsis AP. Immunotherapeutic strategies for glioma treatment. Neuroimmunol Neuroinflammation 2016;3:51-6.

Received: 15-10-2015; Accepted: 05-01-2016 
as loss of major histocompatibility complex (MHC) antigen expression that prevent their recognition by the $\mathrm{CD}^{+}{ }^{\mathrm{T}}$ cells ${ }^{[8]} \mathrm{CD}^{+} \mathrm{T}$ cell cytotoxic activity has been considered key for tumor eradication and these cells have been detected in GBM tissue. Furthermore, the tumor secretes factors that suppress T-cell proliferation and dendritic cells maturation. Increased ratio of $\mathrm{CD} 3$ and $\mathrm{CD}^{+}{ }^{+}$to $\mathrm{FoxP}^{+}{ }^{+} \mathrm{T}$ cell correlated significantly with patient's survival in primary GBM..$^{[9]}$

Further suppression of the immune system in GBM patients can be caused by systematic corticosteroid treatment that is used for the reduction of vasogenic oedema and as a consequence of chemo-radiotherapy. The present review summarizes all major progresses that have been made in immunotherapeutic treatments against gliomas, such as dendritic cells based therapies, vaccines (such as EGFRvIII and IDH1), tumor specific targets, $\mathrm{T}$ cell engineering and immune checkpoint inhibitors.

\section{DENDRITIC CELLS THERAPIES}

Dendritic cells (DC) are professional antigen presenting cells (APC) and have been reported to be a promising treatment method against glioma. DCs can be subdivided into myeloid DC (mDCs) and plasmacytoid DC (pDCs). Dendritic cells can be extracted from blood and can be incubated with GBM cells. After antigen presentations, DC can be injected back to patients as immunotherapy. However, this approach requires firstly, tumor tissue collected during surgery and secondly, several weeks for vaccination preparation. Side effects of this approach are minimal and several studies have shown that DCs are capable of inducing immune response..$^{[10,11]}$ Prins et al. ${ }^{[12]}$ compared the safety, feasibility, and immune responses of malignant glioma patients that were treated with DC pulsed with autologous tumor lysate or with synthetic glioma-associated antigens. The results showed that DCs pulsed with autologous tumor lysates produced a better anti-tumor immune response. ${ }^{[12]}$ When autologous DCs transfected with autologous tumor stem cell-mRNA they induced an immune response against the patient's GBM stem cells. The vaccinated patients had significantly better progressionfree survival. ${ }^{[13]} \mathrm{mDC}$ proved to be superior to $\mathrm{pDC}$ in producing a robust antitumor $\mathrm{T}$ cell response resulting in tumor eradication and better long-term survival in mice. ${ }^{[14]}$ Recently, Mitchell et al. ${ }^{[15]}$ showed that pre-conditioning the site of vaccination with a recall antigen such as tetanus/ diphtheria toxoid can significantly increase the efficacy of DC vaccination.

ApartfromloadingDCwith regularantigens, Xu etal. ${ }^{[16]}$ used cancer stem-like cells (CSC) as sources of antigens for DC vaccination, given that these cells express increased levels of MHCs and tumor associated antigens. This vaccination induced antigen-specific Th1 immune response and, when tested in $9 \mathrm{~L}$ CSCs brain tumor model, it resulted in robust antitumor T-cell immunity and a significant survival benefit. ${ }^{[16]}$ Another interesting approach is the possibility of preloading DC and CD14 ${ }^{+}$cells with chemotherapeutic drugs before immunotherapy. In a recent study, both CD14 ${ }^{+}$ and DCs were incubated with paclitaxel for $24 \mathrm{~h}$. The cells loaded the drug and this was subsequently released in the conditioned medium. Growth inhibition was observed when this medium was used to culture U87MG cells. ${ }^{[17]}$ Of note, U87MG is a commercial cell line that has been expanded in vitro for many passages, thus its utility in defining therapeutic approaches for glioma is questionable.

\section{VACCINES}

The rational for vaccines lies in the presentation of tumor associated antigens in the immune system. Several ways exist to provide antigens for vaccine administration, one of which is autologous DC as previously described. Recently, a vaccine called Gliovac (ERC 1671), was prepared using autologous antigens that derived from excised tumor tissue and were combined with allogeneic antigens from glioma tissue resected from other GBM patients. This vaccine was capable of triggering powerful polyclonal immune reactions. When administered in 9 recurrent GBM patients, that were treated with surgery, radiotherapy, temozolomide and bevacizumab, the vaccine showed minimal toxicity and enhanced overall survival that reached $77 \%$

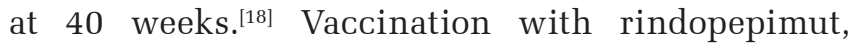
composed of the EGFRvIII peptide sequence conjugated to the immunogenic carrier protein keyhole limpet hemocyanin, showed promise in a phase II study. The median progression-free survival and overall survival was 14.2 and 26 months in vaccinated patients compared to 6.4 and 15.2 months in controls, respectively. ${ }^{[19]}$ A Phase III clinical trial is now underway. One major disadvantage of peptide vaccines is that a different treatment strategy is usually required when tumor recurs. Sampson et al. ${ }^{[20]}$ showed that the EGFRvIII-targeted peptide vaccine triggered loss of the EGFRvIII expression in $82 \%$ of patients at the time of tumor recurrence.

The $\mathrm{R} 132 \mathrm{H}$ mutation is a tumorigenic mutation and can be found in the majority of low grade gliomas, secondary GBMs and rarely on primary GBMs or gliosarcomas. Paradoxically, the presence of mutation is a favorable prognostic marker, even when assessed in comparison with the O6-methylguanine-DNA methyltransferase promoter status. ${ }^{[21]} \mathrm{A}$ vaccine of peptides encompassing 
the mutated region showed great promise for the treatment of (R132H)-mutated tumors. ${ }^{[22]}$ In an intracranial glioma model, the $\mathrm{R} 132 \mathrm{H}$ mutation could be effectively targeted by the immune system: the results of this study demonstrated a significant increase in survival of treated mice compared to controls and $25 \%$ of the mice were cured. After evaluating the $\mathrm{CD}^{+}{ }^{+} \mathrm{T}$ cell response in spleen there was a significant difference for the immunized mice compared to controls. ${ }^{[23]}$

Heat shock proteins (HSP) are evolutionary conserved family of proteins that serve as molecular chaperones and inhibit non specific protein aggregation. ${ }^{[24]}$ HSP can be recognized and activate APC cells which in turn present them on major histocompatibility complexes I (MHC I) and II (MHC II). ${ }^{[25]}$ Various HSP have been utilized for this purpose. Peptides bound to HSP-96 proved safe in a phase I trial and resulted in a 47 weeks median survival after surgical excision in the $11 / 12$ patients that responded to the vaccination. ${ }^{[26]}$ In a phase II study of 41 patients, that received complete excision of recurrent GBM and vaccination, the median overall survival reached 42.6 weeks. ${ }^{[27]}$ The HSP47 was also utilized as a glioma associated antigen. In $26.9 \%$ of GBM patients there was a positive cytotoxic $\mathrm{T}$ lymphocyte response that resulted in a significant better progression-free and overall survival than negative responders. ${ }^{[28]}$ Recently, a vaccine composed of the recombinant mycobacterial HSP65 with mouse glioma 261 (GL261) tissue lysate increased the survival of mice bearing GL261 gliomas by enhancing the ratios of brain-infiltrating Th17 cells subset and inflammatory cells. ${ }^{[29]}$ Of note, although efficient for studies based on anti-glioma therapeutic modalities, GL261 cells exhibit moderate immunogenicity. ${ }^{[30]}$

\section{TUMOR SPECIFIC TARGETS}

Monoclonal antibodies constitute an attractive type of biological therapy. The selection of tumor antigens suitable for antibody targeting and therapy requires firstly, the target antigen to be confined in the tumor and secondly, to be absent or to have a very low expression on normal tissue. Antigens involved in angiogenesis are a suitable target of monoclonal antibodies, in fact GBM is a highly vascular tumor that expresses high levels of the pro-angiogenic vascular endothelial growth factor (VEGF) and VEGF receptors. ${ }^{[31]}$ Hypoxic conditions that are present in this tumor further increase VEGF production. Bevacizumab is a humanized monoclonal immunoglobulin G1 antibody that neutralizes the biological activity of human VEGF-A and inhibits its binding to vascular growth factor receptor 1 (VGFR-1) and VGFR-2 on tumor endothelial cells. ${ }^{[32]}$ Such agent has been approved for the treatment of recurrent GBM and has been also used in combination with cytotoxic agents such as irinotecan with favorable results. ${ }^{[33]}$

Overexpression and/or amplification can be found in up to $40 \%$ of primary GBM. Several EGFR mutations have been reported, the most frequent being EGFRvIII that occurs in $25-64 \%$ of cases. ${ }^{[34]}$ Cetuximab is a chimeric monoclonal antibody against EGFRvIII with high affinity. In a phase II study, involving patients with recurrent GBM, cetuximab combined with bevacizumab and irinotecan was safe, except from skin toxicity and displayed encouraging response rates. Nevertheless, the combination treatment does not seem to be more effective in comparison to bevacizumab and irinotecan alone. ${ }^{[35]}$ Recently, an antibody drug conjugate, named AMG 595 was tested. AMG 595 is composed of maytansinoid DM1, which are potent microtubule-targeted compounds blocking the proliferation of cells at mitosis. After conjugation to an anti-EGFRvIII antibody, it was observed that the drug inhibited the proliferation of U251 cells and induced tumor mitotic arrest in xenografts expressing EGFRvIII. ${ }^{[36]}$

Cancer stem cells display a high tumorigenic potential and treatment resistance, given their low proliferation rate, eventually resulting in GBM recurrence. Targeting GBM stem cells is an attractive treatment strategy and various approaches have been tested. The AC133 epitope expressed on the CD133 glycoprotein has been used as a marker to identify stem cells. Recently, a recombinant specific antibody that binds both to AC133 and to T cells (via the CD3 receptor) has been developed. This agent suppressed the outgrowth of $\mathrm{AC} 133^{+}$subcutaneous GBM xenografts. ${ }^{[37]}$ Nevertheless, it is important to note that CD133 as well as other markers such as CD15, do not discriminate between tumorigenic and non-tumorigenic cells, thus questioning their use in glioma to identify CSCs. ${ }^{[38,39]}$

The highly immunosuppressive tumor microenvironment is considered to be a significant barrier to successful immunotherapy. The fibrinogenlike protein 2 (FGL2) that can be found in malignant cells has been reported to act as an immune-suppressor in GBM, permitting the tumor to grow by suppressing tumor-targeted immune responses. Mice treated with an anti-FGL2 antibody had a median survival of 27 days compared with 17 days as the median survival of mice injected with an isotype control antibody. ${ }^{[40]}$

\section{T CELL ENGINEERING}

Chimeric Antigen Receptor (CAR) cells are cytotoxic 
T lymphocytes (CTL) engineered to express tumor antigen-specific proteins. Such targets are the EGFRvIII, human epidermal growth factor receptor 2, erythropoietin-producing hepatocellular carcinoma A2 (EphA2) and the interleukin-13 receptor alpha2 (IL13R $\alpha 2$ ). Recently, it has been suggested that EGFRvIII-directed CAR $\mathrm{T}$ cells are able to suppress tumors of EGFRvIII (+) GBM in xenogeneic subcutaneous and orthotopic models. ${ }^{[1]}$ The EphA2 has been found increased in the majority of GBM specimens and cell lines and at very low levels in the normal brain. ${ }^{[42]}$ Chow et al. ${ }^{[43]}$ developed EphA2specific $\mathrm{T}$ cells that resulted in regression of glioma xenografts and better survival. The IL13R $\alpha 2$ is a cell surface receptor which is not significantly expressed in normal brain but over-expressed in a subset of high-grade gliomas. Similarly, in a trial evaluating an engineered chimeric antigen receptor, autologous primary human $\mathrm{CD}^{+}$cytotoxic $\mathrm{T}$ lymphocytes targeting IL13Ra2 were tested for the treatment of recurrent GBM. The intracranial administration was safe and promising in a pilot study of 3 patients. ${ }^{[44]}$

\section{IMMUNE CHECKPOINT INHIBITORS}

Immune checkpoint inhibitors against regulatory pathways in T cells provide a gateway to development of new treatments for several cancer types. ${ }^{[4]}$ This has been explored in several tumors, by testing antibodies to cytotoxic $\mathrm{T}$ lymphocyte antigen-4 (CTLA-4), i.e. an important immunosuppressive receptor, inhibition of indoleamine 2,3-dioxygenase 1 (IDO) and blocking antibodies targeting either the receptor of the programmed death 1 (PD-1) checkpoint or its major ligand. For instance, in a murine GL261 glioma model, a long-term survival in at least $50 \%$ of treated animals was achieved by combining radiotherapy with anti-CTLA-4 antibodies and anti-4-1BB, that drives the proliferation of $\mathrm{CD}^{+} \mathrm{T}$ cells. ${ }^{[46]}$ Moreover, using a syngeneic intracranial mouse glioma model, Wainwright et $a .^{[47]}$ reported that simultaneous blockage of CTLA-4, IDO and PD-L1 results in long term survival of all mice.

\section{OTHER APPROACHES}

Another interesting approach is based on macrophages which have the ability to cross the intact blood brain barrier. Baek et al. ${ }^{[48]}$ showed that macrophages loaded with gold nanoshells could infiltrated into glioma spheroids and after near-infrared light laser irradiation there was complete growth inhibition in an irradiance-dependent manner. Recently, allogeneic natural killer (NK) cells against patientderived GBM in vitro and in vivo have been tested with promising results. Killer Ig-like receptor (KIR)
2DS2 positive NK cell subsets displayed a functional activation advantage and resulted in greater cytokine production, propensity for degranulation and greater persistence in vivo compared with KIR2DS2 negative NK cells. ${ }^{[49]}$ In order to enhance the killing capability of cytotoxic lymphocytes, another approach was based on the modulation of microvilli and filopodia that are characteristic of glioma cells. These structures physically prevent cytolytic lymphocytes from eliminating glioma cells. In particular, knockingdown Fascin-1, an important scaffolding protein that is involved in the microvilli and filopodia formation, resulted in increased lymphocyte cytotoxicity and inhibition of cell proliferation and invasion. ${ }^{[50]}$ Recently, the intratumoral administration of an oncolytic adenovirus, the AdCMVdelta24, led to an increased number of Interferon gamma-producing $\mathrm{CD}^{+} \mathrm{T}$ cells and a decrease in the tumor-infiltrating regulatory $\mathrm{T}$ cells in a mouse model. ${ }^{[51]}$

Interestingly, it has been suggested that radiotherapy complement immunotherapies; in fact, irradiated cancer cells release peptides that can activate DC. Furthermore, radiotherapy in combination with immune checkpoint inhibitors such as (anti-CTLA-4 and/or anti-PD-L1) may stimulate $\mathrm{CD}^{+} \mathrm{T}$ cellmediated anti-tumor immunity. ${ }^{[52]}$

\section{CONCLUSION}

GBM is an extremely heterogeneous tumor, comprised of both differentiated and stem cells. ${ }^{[53]}$ This is also highlighted in the recent gene expressionbased molecular classification of GBM into four subtypes, namely Proneural, Neural, Classical and Mesenchymal. ${ }^{[3]}$ Thus, a multifaceted approach combining several treatment strategies might be eventually required to achieve better results. Recent data seem to suggest that immunotherapy constitutes a promising treatment strategy for malignant gliomas despite several limitations such as the modest Class I MHC expression and the absence of Class II MHC expression in tumor cells. Further combinatorial treatments that involve the current standard therapies and immunotherapeutic approaches are under way and hopefully they will lead to more promising results.

Financial support and sponsorship Nil.

Conflicts of interest

There are no conflicts of interest.

\section{REFERENCES}

1. Liu Y, Shete S, Etzel CJ, Scheurer M, Alexiou G, Armstrong G, Tsavachidis S, Liang FW, Gilbert M, Aldape K, Armstrong T, Houlston 
R, Hosking F, Robertson L, Xiao Y, Wiencke J, Wrensch M, Andersson U, Melin BS, Bondy M. Polymorphisms of LIG4, BTBD2, HMGA2, and RTEL1 genes involved in the double-strand break repair pathway predict glioblastoma survival. J Clin Oncol 2010;28:2467-74.

2. Alexiou GA, Goussia A, Voulgaris S, Fotopoulos AD, Fotakopoulos G, Ntoulia A, Zikou A, Tsekeris P, Argyropoulou MI, Kyritsis AP. Prognosticsignificance of MRP5 immunohistochemical expression in glioblastoma. Cancer Chemotherapy and Pharmacology 2012;69:1387-91.

3. Verhaak RG, Hoadley KA, Purdom E, Wang V, Qi Y, Wilkerson MD Miller CR, Ding L, Golub T, Mesirov JP, Alexe G, Lawrence M, O'Kelly M, Tamayo P, Weir BA, Gabriel S, Winckler W, Gupta S, Jakkula L, Feiler HS, Hodgson JG, James CD, Sarkaria JN, Brennan C, Kahn A, Spellman PT, Wilson RK, Speed TP, Gray JW, Meyerson M, Getz G, Perou CM, Hayes DN; Cancer Genome Atlas Research Network. Integrated genomicanalysis identifies clinically relevant subtypes of glioblastomacharacterized by abnormalities in PDGFRA, IDH1, EGFR, and NF1. Cancer Cell 2010;17:98-110.

4. Weathers SP, Gilbert MR. Current challenges in designing GBM trials for immunotherapy. J Neurooncol 2015;123:331-7.

5. Decker WK, Safdar A. Bioimmunoadjuvants for the treatment of neoplastic and infectious disease: Coley's legacy revisited. Cytokine Growth Factor Rev 2009;20:271-81.

6. Alexiou GA, Kallinteri A, Michos E, Zagorianakou P, Priavali E, Pachatouridis D, Levidiotou S, Voulgaris S. The influence of postoperative infection in survival of patients with high-grade gliomas. Neuroimmunol Neuroinflammation 2015;2:18-20.

7. Alexiou GA, Vartholomatos E, Zagorianakou P, Voulgaris S. Prognostic significance of neutrophil-to-lymphocyte ratio in glioblastoma. Neuroimmunol Neuroinflammation 2014;1:131-4.

8. Gomez GG, Kruse CA. Mechanisms of malignant glioma immune resistance and sources of immunosuppression. Gene Ther Mol Biol 2006;10:133-146.

9. Sayour EJ, McLendon P, McLendon R, De Leon G, Reynolds R, Kresak J, Sampson JH, Mitchell DA. Increased proportion of FoxP3+ regulatory $\mathrm{T}$ cells in tumor infiltrating lymphocytes is associated with tumor recurrence and reduced survival in patients with glioblastoma. Cancer Immunol Immunother 2015;64:419-27.

10. Liau LM, Prins RM, Kiertscher SM, Odesa SK, Kremen TJ, Giovannone AJ, Mischel PS, Cloughesy TF, Roth MD. Dendritic cell vaccination in glioblastoma patients induces systemic and intracranial T-cell responses modulated by the local central nervous system tumor microenvironment. Clin Cancer Res 2005;11:5515-25.

11. De Vleeschouwer S, Fieuws S, Rutkowski S, Van Calenbergh F, Van Loon J, Goffin J, Sciot R, Wilms G, Demaerel P, Warmuth-Metz M, Soerensen N, Wolff JE, Wagner S, Kaempgen E, Van Gool SW. Postoperative adjuvant dendritic cell-based immunotherapy in patients with relapsed glioblastoma multiforme. Clin Cancer Res 2008;14:3098-104

12. Prins RM, Wang X, Soto H, Young E, Lisiero DN, Fong B, Everson R, Yong WH, Lai A, Li G, Cloughesy TF, Liau LM. Comparison of glioma-associated antigen peptide-loaded versus autologous tumor lysate-loaded dendritic cell vaccination in malignant glioma patients. J Immunother 2013;36:152-7.

13. Vik-Mo EO, Nyakas M, Mikkelsen BV, Moe MC, Due-Tønnesen P, Suso EM, Sæbøe-Larssen S, Sandberg C, Brinchmann JE, Helseth E, Rasmussen AM, Lote K, Aamdal S, Gaudernack G, Kvalheim G, Langmoen IA. Therapeutic vaccination against autologous cancer stem cells with mRNA-transfected dendritic cells in patients with glioblastoma. Cancer Immunol Immunother 2013;62:1499-509.

14. Dey M, Chang AL, Miska J, Wainwright DA, Ahmed AU, Balyasnikova IV, Pytel P, Han Y, Tobias A, Zhang L, Qiao J, Lesniak MS. Dendritic Cell-Based Vaccines that Utilize Myeloid Rather than Plasmacytoid Cells Offer a Superior Survival Advantage in Malignant Glioma. $J$ Immunol 2015;195:367-76

15. Mitchell DA, Batich KA, Gunn MD, Huang MN, Sanchez-Perez L, Nair SK, Congdon KL, Reap EA, Archer GE, Desjardins A, Friedman AH, Friedman HS, Herndon JE 2nd, Coan A, McLendon RE, Reardon DA, Vredenburgh JJ, Bigner DD, Sampson JH. Tetanus toxoid and CCL3 improve dendritic cell vaccines in mice and glioblastoma patients. Nature 2015;519:366-9.

16. Xu Q, Liu G, Yuan X, Xu M, Wang H, Ji J, Konda B, Black KL, Yu JS
Antigen-specific T-cell response from dendritic cell vaccination using cancer stem-likecell-associated antigens. Stem Cells 2009;27:1734-40.

17. Bonomi A, Lisini D, Navone SE, Frigerio S, Dossena M, Ciusani E, Rampini P, Marfia G, Coccè V, Cavicchini L, Sisto F, Parati E, Mantegazza R, Rimoldi M, Rizzetto M, Alessandri G, Pessina A. Human CD14+ cells loaded with Paclitaxel inhibit in vitro cell proliferation of glioblastoma. Cytotherapy 2015;17:310-9.

18. Schijns VE, Pretto C, Devillers L, Pierre D, Hofman FM, Chen TC, Mespouille P, Hantos P, Glorieux P, Bota DA, Stathopoulos A. First clinical results of a personalized immunotherapeutic vaccine against recurrent, incompletely resected treatment-resistant glioblastoma multiforme (GBM) tumors, based on combined allo- and auto-immune tumor reactivity. Vaccine 2015;33:2690-6.

19. Schuster J, Lai RK, Recht LD, Reardon DA, Paleologos NA, Groves MD, Mrugala MM, Jensen R, Baehring JM, Sloan A, Archer GE, Bigner DD, Cruickshank S, Green JA, Keler T, Davis TA, Heimberger $\mathrm{AB}$, Sampson JH. A phase II, multicenter trial of rindopepimut (CDX$110)$ in newly diagnosed glioblastoma: the ACT III study. Neuro Oncol 2015;17:854-61.

20. Sampson JH, Heimberger AB, Archer GE, Aldape KD, Friedman AH, Friedman HS, Gilbert MR, Herndon JE 2nd, McLendon RE, Mitchell DA, Reardon DA, Sawaya R, Schmittling RJ, Shi W, Vredenburgh JJ, Bigner DD. Immunologic escape after prolonged progressionfree survival with epidermal growth factor receptor variant III peptide vaccination in patients with newly diagnosed glioblastoma. J Clin Oncol 2010;28:4722-9.

21. Lewandowska MA, Furtak J, Szylberg T, Roszkowski K, Windorbska W, Rytlewska J, Jóźwicki W. An analysis of the prognostic value of IDH1 (isocitrate dehydrogenase 1) mutation in Polish glioma patients. Mol Diagn Ther 2014;18:45-53.

22. Schumacher T, Bunse L, Pusch S, Sahm F, Wiestler B, Quandt J, Menn O, Osswald M, Oezen I, Ott M, Keil M, Balß J, Rauschenbach K, Grabowska AK, Vogler I, Diekmann J, Trautwein N, Eichmüller SB, Okun J, Stevanović S, Riemer AB, Sahin U, Friese MA, Beckhove P, von Deimling A, Wick W, Platten M. A vaccine targeting mutant IDH1 induces antitumour immunity. Nature 2014;512:324-7.

23. Pellegatta S, Valletta L, Corbetta C, Patanè M, Zucca I, Riccardi Sirtori F, Bruzzone MG, Fogliatto G, Isacchi A, Pollo B, Finocchiaro G. Effective immuno-targeting of the IDH1 mutation $\mathrm{R} 132 \mathrm{H}$ in a murine model of intracranial glioma. Acta Neuropathol Commun 2015;3:4.

24. Alexiou GA, Vartholomatos G, Stefanaki K, Patereli A, Dova L, Karamoutsios A, Lallas G, Sfakianos G, Moschovi M, Prodromou N. Expression of heat shock proteins in medulloblastoma. $J$ Neurosurg Pediatr 2013;12:452-7.

25. Nishikawa M, Takemoto S, Takakura Y. Heat shock protein derivatives for delivery of antigens to antigen presenting cells. Int $J$ Pharm 2008;354:23-7.

26. Crane CA, Han SJ, Ahn B, Oehlke J, Kivett V, Fedoroff A, Butowski N, Chang SM, Clarke J, Berger MS, McDermott MW, Prados MD, Parsa AT. Individual patient-specific immunity against high-grade glioma after vaccination with autologous tumor derived peptides bound to the 96 KD chaperone protein. Clin Cancer Res 2013;19:205-14.

27. Bloch O, Crane CA, Fuks Y, Kaur R, Aghi MK, Berger MS, Butowski NA, Chang SM, Clarke JL, McDermott MW, Prados MD, Sloan AE, Bruce JN, Parsa AT. Heat-shock protein peptide complex-96 vaccination for recurrent glioblastoma: a phase II, single-arm trial. Neuro Oncol 2014;16:274-9.

28. Wu ZB, Cai L, Qiu C, Zhang AL, Lin SJ, Yao Y, Xu J, Zhou LF. CTL responses to HSP47 associated with the prolonged survival of patients with glioblastomas. Neurology 2014;82:1261-5

29. Yan Y, Fang M, Xuan W, Wu X, Meng X, Wang L, Yu Y. The Therapeutic Potency of HSP65-GTL in GL261 Glioma-bearing Mice. J Immunother 2015;38:341-9.

30. Szatmári T, Lumniczky K, Désaknai S, Trajcevski S, Hídvégi EJ, Hamada H, Sáfrány G. Detailed characterization of the mouse glioma 261 tumor model for experimental glioblastoma therapy. Cancer Sci 2006;97:546-53.

31. Huang H, Held-Feindt J, Buhl R, Mehdorn HM, Mentlein R. Expression of VEGF and its receptors in different brain tumors. Neurol Res 2005;27:371-7.

32. Ferrara N, Hillan KJ, Novotny W. Bevacizumab (Avastin), a humanized anti-VEGF monoclonal antibody for cancer therapy. Biochem 
Biophys Res Commun 2005;333:328-35.

33. Vredenburgh JJ, Desjardins A, Herndon JE 2nd, Marcello J, Reardon DA, Quinn JA, Rich JN, Sathornsumetee S, Gururangan S, Sampson J, Wagner M, Bailey L, Bigner DD, Friedman $\mathrm{AH}$, Friedman HS. Bevacizumab plus irinotecan in recurrent glioblastoma multiforme. J Clin Oncol 2007;25:4722-9.

34. Gan HK, Cvrljevic AN, Johns TG. The epidermal growth factor receptor variant III (EGFRvIII): where wild things are altered. FEBS J 2013;280:5350-70.

35. Hasselbalch B, Lassen U, Hansen S, Holmberg M, Sørensen M, Kosteljanetz M, Broholm H, Stockhausen MT, Poulsen HS. Cetuximab, bevacizumab, and irinotecan for patients with primary glioblastoma and progression after radiation therapy and temozolomide: a phase II trial. Neuro Oncol 2010;12:508-16.

36. Hamblett KJ, Kozlosky CJ, Siu S, Chang WS, Liu H, Foltz IN, Trueblood ES, Meininger D, Arora T, Twomey B, Vonderfecht SL, Chen Q, Hill JS, Fanslow WC. AMG 595, an Anti-EGFRvIII AntibodyDrug Conjugate, Induces Potent Antitumor Activity against EGFRvIIIExpressing Glioblastoma. Mol Cancer Ther 2015;14:1614-24.

37. Prasad S, Gaedicke S, Machein M, Mittler G, Braun F, Hettich M, Firat E, Klingner K, Schüler J, Wider D, Wäsch RM, Herold-Mende C, Elsässer-Beile U, Niedermann G. Effective Eradication of Glioblastoma Stem Cells by Local Application of an AC133/CD133-Specific T-cellEngaging Antibody and CD8 T Cells. Cancer Res 2015;75:2166-76.

38. Lottaz C, Beier D, Meyer K, Kumar P, Hermann A, Schwarz J, Junker M, Oefne PJ, Bogdahn U, Wischhusen J, Spang R, Storch A, Beier CP. Transcriptional profiles of CD133+ and CD133- glioblastomaderived cancer stem celllinessuggestdifferentcells of origin. Cancer Res 2010;70:2030-40.

39. Brescia P, Richichi C, Pelicci G. Currentstrategies for identification of glioma stem cells: adequate or unsatisfactory? $J$ Oncol 2012;2012:376894.

40. Yan J, Kong LY, Hu J, Gabrusiewicz K, Dibra D, Xia X, Heimberger AB, Li S. FGL2 as a Multimodality Regulator of Tumor-Mediated Immune Suppression and Therapeutic Target in Gliomas. J Natl Cancer Inst 2015;107.

41. Johnson LA, Scholler J, Ohkuri T, Kosaka A, Patel PR, McGettigan SE, Nace AK, Dentchev T, Thekkat P, Loew A, Boesteanu AC, Cogdill AP, Chen T, Fraietta JA, Kloss CC, Posey AD Jr, Engels B, Singh R, Ezell T, Idamakanti N, Ramones MH, Li N, Zhou L, Plesa G, Seykora JT, Okada H, June CH, Brogdon JL, Maus MV. Rational development and characterization of humanized anti-EGFR variant III chimeric antigen receptor T cells for glioblastoma. Sci Transl Med 2015;7:275ra22.

42. Wykosky J, Gibo DM, Stanton C, Debinski W. EphA2 as a novel molecular marker and target in glioblastoma multiforme. Mol Cancer Res 2005;3:541-51.

43. Chow KK, Naik S, Kakarla S, Brawley VS, Shaffer DR, Yi Z, Rainusso
N, Wu MF, Liu H, Kew Y, Grossman RG, Powell S, Lee D, Ahmed N, Gottschalk S. T cells redirected to EphA2 for the immunotherapy of glioblastoma. Mol Ther 2013;21:629-37.

44. Brown CE, Badie B, Barish ME, Weng L, Ostberg JR, Chang WC, Naranjo A, Star R, Wagner J, Wright C, Zhai Y, Bading JR, Ressler JA, Portnow J, D'Apuzzo M, Forman SJ, Jensen MC. Bioactivity and Safety of IL13R $\alpha 2$-Redirected Chimeric Antigen Receptor CD8+ T Cells in Patients with Recurrent Glioblastoma. Clin Cancer Res 2015:21:4062-72.

45. Sharma P, Allison JP. The future of immune checkpoint therapy. Science 2015;348:56-61.

46. Belcaid Z, Phallen JA, Zeng J, See AP, Mathios D, Gottschalk C, Nicholas S, Kellett M, Ruzevick J, Jackson C, Albesiano E, Durham NM, Ye X, Tran PT, Tyler B, Wong JW, Brem H, Pardoll DM, Drake CG, Lim M. Focal radiation therapy combined with 4-1BB activation and CTLA-4 blockade yields long-term survival and a protective antigen-specific memory response in a murine glioma model. PLoS One 2014;9:e101764.

47. Wainwright DA, Chang AL, Dey M, Balyasnikova IV, Kim CK, Tobias A, Cheng Y, Kim JW, Qiao J, Zhang L, Han Y, Lesniak MS. Durable therapeutic efficacy utilizing combinatorial blockade against IDO, CTLA-4, and PD-L1 in mice with brain tumors. Clin Cancer Res 2014;20:5290-301

48. Baek SK, Makkouk AR, Krasieva T, Sun CH, Madsen SJ, Hirschberg $\mathrm{H}$. Photothermaltreatment of glioma; an in vitro study of macrophagemediateddelivery of gold nanoshells. J Neurooncol 2011;104:439-48.

49. Gras Navarro A, Kmiecik J, Leiss L, Zelkowski M, Engelsen A, Bruserud $\varnothing$, Zimmer J, Enger P $\varnothing$, Chekenya M. NK cells with KIR2DS2 immunogenotype have a functional activation advantage to efficiently kill glioblastoma and prolong animal survival. J Immunol 2014;193:6192-206.

50. Hoa NT, Ge L, Erickson KL, Kruse CA, Cornforth AN, Kuznetsov Y, McPherson A, Martini F, Jadus MR. Fascin-1 knock-down of human glioma cells reduces their microvilli/filopodia while improving their susceptibility to lymphocyte-mediated cytotoxicity. Am J Transl Res 2015;7:271-84

51. Qiao J, Dey M, Chang AL, Kim JW, Miska J, Ling A, M Nettlebeck D, Han Y, Zhang L, Lesniak MS. Intratumoral oncolytic adenoviral treatment modulates the glioma microenvironment and facilitates systemic tumor-antigen-specific T cell therapy. Oncoimmunology 2015:4:e1022302.

52. Derer A, Frey B, Fietkau R, Gaipl US. Immune-modulating properties of ionizing radiation: rationale for the treatment of cancer by combination radiotherapy and immune checkpoint inhibitors. Cancer Immunol Immunother doi: 10.1007/s00262-015-1771-8.

53. Assimakopoulos A, Polyzoidis K, Kyritsis AP. Stem cells in gliomas. $J$ Stem Cells Res Rev \& Rep 2014;1:1009. 